Article

\title{
(Human-Inflected) Evolution in an Age of (Human-Induced) Extinction: Synthetic Biology Meets the Anthropocene
}

\author{
Josh Wodak \\ Institute Culture and Society, Western Sydney University, Sydney 2150, Australia; \\ j.wodak@westernsydney.edu.au
}

Received: 13 July 2020; Accepted: 16 October 2020; Published: 23 October 2020

check for updates

\begin{abstract}
At the advent of the Anthropocene, life is being pushed to its limits the world over; we are currently living through the Sixth Mass Extinction to occur since multicellular life first emerged on the planet 570 million years ago. Evolutionary biologist E.O. Wilson sums up this push in the opening gambit of his book The Future of Life: "the race is now on between the techno-scientific forces that are destroying the living environment and those that can be harnessed to save it". Contra Wilson, this paper addresses the paradox arising from proposals to harness "techno-scientific forces ... to save" the "living environment" while other forces continue to destroy it. By framing human-inflected evolution in an age of human-induced extinction, this article asks what could or should conservation become, if 'conserving' imperiled species might now require genetic interventions of the synthetic kind. Drawing upon recent key markers of "the race", this paper presents a notional conservation for the Anthropocene-namely, that such a conservation proposes active intervention not only into ecosystems but into evolution itself. And yet, such interventions can only be considered in the context of the planetary scale that is the Anthropocene-writ-large, as per the desertification of the Amazon or the collapse of Antarctic ice sheets, the spatial scale of the microbial world, and on the temporal scale of evolution. Viewed within such a context, this paper presents technoscientific conservation as paradoxically being both vital and futile, as well as timely and too late.
\end{abstract}

Keywords: cultural imaginary; environmental humanities; environmental ethics; synthetic biology; conservation biology; microbiology; Anthropocene evolution

\section{Trendsetting}

The journal in question is called Trends in Ecology and Evolution. The article in question is called 'Is It Time for Synthetic Biodiversity Conservation?'. Given the current trends in ecology and evolution-from the climate crisis to the unfolding Sixth Extinction Event and beyond-the answer would appear to be self-evident. Yes, it is time. Time for what though? And when, where, what, how, and by whom? But, most importantly: why? Why is it that 'conserving' imperilled species might now require genetic interventions of the synthetic kind?

Probing whether it is actually "Time for Synthetic Biodiversity Conservation" poses a question which begets the thoroughly inhuman, nonhuman, and more-than-human domains at play. Namely, that any such proposed conservation must be considered in context, not only on the planetary scale that is the Anthropocene-writ-large, as per the desertification of the Amazon or the collapse of Antarctic ice sheets, but on the spatial scale of the microbial world, on the temporal scale of evolution, as well as within the affective domain of the cultural imaginary that underpins technoscientific conservation. Because, if it is indeed time for measures such as Synthetic Biology Conservation, then any notional conservation not cognisant of the vastly different scales at play is as anachronistic as Holocene worldviews of both humanity and the humanities. 
This article offers a framework for any such conservation, through recourse to key moments in the nascent field of technoscientific conservation. These key moments illuminate the paradoxes facing conservation, by which it appears to be both vital and futile, as well as timely and too late. This means that the real question within the question of whether it is indeed "Time for Synthetic Biodiversity Conservation" is actually whether it is too late for conservation by any means at all.

In an age of human-induced extinction on a global scale, synthetic biology is human-inflected evolution, albeit on the microbial scale, and predominantly used for perpetuating so-called human civilisation rather than benefiting the more-than-human living world. The field aims to synthesise microbial organisms into 'biofactories', whereby their metabolism is directed towards making medicines, bioplastics, or biofuels. This applies to microbes that have already been co-opted for human benefit since the proverbial dawn of civilisation, such as yeast for beer and bread, as well as microbes with much more recent human entanglements, through to currently non-existent but seriously proposed new-to-nature microbes notionally designed to fulfil specific desired outcomes. While the field is highly diverse, it is unified by a promissory zeal, which maintains that successful synthesis will allow for the prodigious productivity of the microbial world to be harnessed into biomanufacturing (such as swapping biofuels for fossil fuels, or bioplastic for petroleum-derived plastic), producing lower biophysical impacts.

The seismic potential of this endeavour drives both industrial and academic research, and, while synthetic biology pursues human-induced evolution of affected microbes, this paper is concerned with proposed conservation usage rather than normative applications. The potential efficacy for such usage throws the manifold objections to normative synthetic biology into a different light if, and only if, it is actually "Time for Synthetic Biodiversity Conservation". This raises a seemingly irresolvable tension: what if the potential efficacy of synthetic biology for conservation in turn serves to justify and legitimise the field-in-general, including its normative applications? If the "mission-oriented crisis discipline" (Soulé 1985, p. 11) that is conservation biology leverages technologies that are overwhelmingly intended for sustaining so-called human civilisation, does this then obviate the ethical and moral objections to the field?

The 'Is It Time?' article, published in February 2017, did not have to wait long for an answer to its question. In September that year, 18 Australian scientists published what amounted to a reply in Nature Ecology and Evolution: 'New Interventions are Needed to Save Coral Reefs', declaring "that emerging interventions such as assisted gene flow, assisted evolution, synthetic biology and habitat engineering, operating at the appropriate organismal or ecosystem levels, are essential to build reef resilience" (Anthony et al. 2017, p. 1420). The three-page article does not explicitly propose such interventions for the Great Barrier Reef in Australia, but the co-authors' specialised focus on this, the largest living organism on earth, left little doubt as to which reefs they had in mind.

A week before 'New Interventions' was published, 43 scientists held a workshop at Heron Island Research Station on the Great Barrier Reef, on the subject of 'Engineering Resilience.' The scientists, many of whom had co-authored 'Is It Time?' or 'New Interventions', were meeting to explore the application of synthetic biology out of the microbial scale, and into much larger organisms. While the principal aim of this workshop was to explore the efficacy of increasing the thermal tolerance of coral toward rising ocean temperatures, engineering such resilience goes beyond coral, to diverse kinds of flora and fauna. Similar proposals exist for specific flora and fauna that are arguably amenable to genetic intervention, in cases where all other options appear insufficient in terms of already precipitously vulnerable populations (Coleman and Goold 2019; Redford et al. 2013, 2019).

Such proposals offer a riposte to The Future of Life as per evolutionary biologist E.O. Wilson in his book of this title. For Wilson, "the race is now on between the techno-scientific forces that are destroying the living environment and those that can be harnessed to save it" (Wilson 2003, p. xii). Wherein, scientists such as the authors of 'Is it Time?' or 'New Interventions' would counter: what if harnessing the techno-scientific forces of synthetic biology becomes part of the "race" between "destroying the living environment" and "forces ... to save it"? This is because the 'Is It Time?' question 
mark heralds a larger endeavour across the sciences, one comprising radical proposed responses to the Anthropocene, all offered with seemingly innocuous question mark titles. Here, there are two articles of note: complex systems theorist Richard Solé's 'Bioengineering the Biosphere?', published in Ecological Complexity in 2015, and atmospheric chemist Paul Crutzen's 'Albedo Enhancement by Stratospheric Sulfur Injections: A Contribution to Resolve a Policy Dilemma?' published in Climatic Change in 2006 (Solé 2015; Crutzen 2006).

While these two articles refer, respectively, to intervening in the biosphere and the atmosphere, they share the interventionist ethos that underpins synthetic biology usage in conservation. Indeed, this ethos is problematically implied by the notion of the Anthropocene itself, at least for scientists of the 'Engineering Resilience' and 'Is It Time?' schools of thought. The genealogy of this ethos can be traced back to Paul Crutzen, who first coined and popularised the term 'Anthropocene' in 2000. In a 2011 blog co-authored with Christian Schwägerl, Crutzen brought this ethos together with its multi-scale domains:

Albeit clumsily, we are taking control of Nature's realm, from climate to DNA ... What we do now already affects the planet of the year 3000 or even 50,000. Changing the climate for millennia to come is just one aspect. By cutting down rainforests, moving mountains to access coal deposits and acidifying coral reefs, we fundamentally change the biology and the geology of the planet. While driving uncountable numbers of species to extinction, we create new life forms through gene technology, and, soon, through synthetic biology. (Crutzen and Schwägerl 2011)

In this sense, when the 13 co-authors of 'Is It Time?' asked their probing question, they were effectively asking whether it is time to wield the radical and risky tools of technoscience against the onslaught of the Anthropocene. It is not Wilson's Future of Life that is at stake here, since even if all such technoscientific conservation were to be attempted wholesale, all such interventions are inextricably entangled with inhuman, nonhuman, and more-than-human forcings, from viral irruptions to volcanic eruptions. What is at stake is rather any potential future at all for those lifeforms currently caught in a world undergoing biophysical change too rapid for them to adapt to, save by means of human-induced evolution that closes the gap by 'Engineering Resilience'.

Humanistic responses to the Anthropocene should offer a critical lens through which we can observe how the cultural imaginary configures support or objection to such proposals. The perennial questions of the human condition do not disappear into the Anthropocene, but are rather ever-present and ever-pertinent to proposals to move from "albeit clumsily ... taking control of Nature's realm" to intentionally taking control in the not-too-distant future. At stake here is an ontological condition that undermines any simplistic grounds for supporting or objecting to such proposed synthetic biology usage. Because, if it is actually time to use synthetic biology for conservation, then 'Trends in [Anthropocene] Ecology and Evolution' will bear the mark of human intention, as a counterpoint to the current unintentional desecration caused by those "techno-scientific forces that are destroying the living environment".

Intentional marks would be registered in the genome of species modified through synthetic biology, alongside the existing unintentional marks of human-induced desecration of the more-than-human living word. Such marks in the evolutionary record are analogous to the Anthropocene's boundary layer, which will persist through the earth's strata over geological time scales. This is simply because species subject to any human intervention that successfully confers evolutionary benefits will carry discrete genotypic marks in their human-inflected phylogenesis. Not in the domain of synthetic yeast co-opted into doing the bidding of so-called civilisation, but in the plants and animals bearing synthesised genes that have increased their capacity to adapt to prevailing biophysical conditions. In the instance of coral subjected to synthetic biology, their evolution would be ontologically unique, no longer described in journals with titles such as Nature Ecology and Evolution, but rather titles such as Anthropocene Ecology and Evolution. 


\section{Life Is But a Dream}

Underpinning such dreams of redemption lies the cultural imaginary where more-than-human nature is coupled to technoscience. Regardless of whether or not it was born from sheer necessity born of the fierce urgency of the climate crisis, if this dream is to avoid becoming yet another waking nightmare, then there is much to be unpacked in terms of the culture that is willing the dream into being. Probing this dream is timely because, at present, it is a promise without any demonstrable means of deliverance or guarantee, set against the context of recent historic failures to deliver on prior promises for salvation through biofuels, bioplastic, bioremediation or other bio-based technofixes. As environmental philosopher Christopher Preston argues in his 2018 book The Synthetic Age: Outdesigning Evolution, Resurrecting Species, and Reengineering Our World:

The changes we are facing are much more significant than the familiar litany of human impacts such as climate change, species extinction, and toxic pollution. Earth is entering a period in which some of its most fundamental processes are being co-opted and redesigned by engineers. Synthetic biologists, climate engineers, and nanotechnologists are reaching deeply enough into the workings of nature to alter the very metabolism of the planet we inhabit. In so doing, they promise to create an entirely new, synthetic world. (Preston 2018, dust jacket)

For many, including the authors of strident humanities and social sciences critiques, the "promise" of "an entirely new, synthetic world" is one that will ideally never be fulfilled. These authors object to synthetic biology because, as a promissory technofix, even if it could provide material guarantees against material loss, it would still leave unaddressed the profound inequities of race, gender, and class that have disproportionately fuelled the ecological crisis, and by which the differentiated Anthropos of the Anthropocene suffers its fate. These critiques from the humanities and social sciences call instead for the curbing of capitalism, consumerism, and related hegemonic socio-cultural inequities, rather than continuing to dream of technofix substitutions (Latour 2004; Williams 1980; Wodak 2019).

Evidently, an unassailable chasm separates those in favour versus those against a Synthetic Age. While vehemently disagreeing about intentional interventions into evolution via technoscience, both sides acknowledge that the other's stance is based on a philosophy, or rather a worldview, for how to inhabit earth in the face of impending extinction of incalculable multitudes, including our own species. Those in favour largely pivot their support on the fact that attempts to curb capitalism, consumerism and the like have been an abject failure, as has conventional conservation, which will prove even less effective in the face of biophysical change that is only going to increase in velocity and intensity. Therefore, in this line of argument, the efficacy of synthetic biology must be researched as a potential response.

Those who object do so largely on the grounds that the history of scientific and technological developments is rife with well-intended remedies for a societal or ecological ailment, that instead resulted in the ailment persisting and flourishing, alongside whatever deleterious side-effects of the technoscience used to 'fix' it. From atomic energy to the atomic bomb, or antibiotics to antibiotic resistance, even a cursory acknowledgment of recent technoscientific history shows a disconcerting pattern of undeliverable promises, which lead instead to multifarious and intractable novel calamities. For instance, in 1998 Nigel Clark presented a critique on 'Nanoplanet: Molecular Engineering in the Time of Ecological Crisis' that still applies today:

What is both heartening and horrifying about the speculative regime of molecular engineering is that it offers a technological response to these very issues [the ecological crisis]: heartening because its logic of maximal effects from a minimal intervention promises to bridge the temporal chasm between awareness of an environmental problem and effective action, [and] horrifying because a solution of this nature inevitably has so much in common with the problem it addresses. (Clark 1998, p. 357) 
It is both telling and profoundly troubling that this state of affairs describes the same chasm between those who find today's dream of a Synthetic Age "heartening" and those who find it "horrifying". For instance, some of the earliest research into oil spill bioremediation examined the possibility of genetically engineering bacteria that could break down the crude oil. This also provided the first patent of a lifeform, when the microbiologist Ananda Chakrabarty won his case in the U.S. Supreme Court in 1980 and gained the right to patent his genetically engineered Pseudomonas genus bacterium. Nonetheless, despite an intervening four decades of seismic research in this arena, harnessing lifeforms to ameliorate oil spills remains a dream, not least because, like all dreams, the vision is not shared; for oil companies, the prospect of a microorganism that can eat their reserves is a nightmare that they most definitely do not want realised.

For Clark, these "heartening" and "horrifying" spectres held particular relevance to genetic engineering and subsequently to its direct descendant, synthetic biology. The contemporary relevance of Clark's (1998) critique of molecular engineering is also apparent in his 1997 critique of genetic engineering, which according to his arguments represented

the culmination of the modern drive to master the natural world [through] the application of technical rationality to its most infinitesimal and intimate recesses. The attempt to assert control over bio-physical processes at this level courts disaster of a kind which is without precedent in the history of human interventions. (Clark 1997, p. 77)

Clark drew upon Steven Spielberg's Jurassic Park as a representation of the contemporaneous cultural imaginary of genetic engineering. Nowadays, the fictional de-extinction is pursued through another application of synthetic biology, which is to resurrect extinct species such as the woolly mammoth and the passenger pigeon. What was merely a fable about the folly of human hubris in 1997 is now pursued as real-world response to the Sixth Extinction Event.

The title of Clark's (1997) article, 'Panic Ecology: Nature in the Age of Superconductivity' still haunts today's dream of redemption, as does his 'Nanoplanet' article. Clark's "heartening" receptivity toward molecular and genetic engineering soon came to reside firmly within those who found the prospect "horrifying", even as we became "the victims of bio-tech 'imagineering'" according to philosopher Eugene Thacker in 2003, due to a "blatant disparity between hyper-optimism and an overall lack of concrete results (Thacker 2003, p. 106)". A decade later, in 2013, philosopher Bensaude-Vincent found the discrepancy had only worsened, due to how

the futuristic visions of today technoscientists are strikingly amnesic, so detached from the past that they are totally abstract. In particular, Synthetic Biology is often promoted as a source of technological fixes ... But the concern with the damages due to the previous generations of 'new technologies' does not invite reflections about the next new generations, i.e., the long-term unintended consequences of all technological innovations. (Bensaude-Vincent 2013, p. 30)

Like Thacker, Bensaude-Vincent locates the cultural imaginary of technoscience as driving the dream of redemption, wherein "in Synthetic Biology and recent biotechnologies, imagination takes a more positive and important role, which is by no means in contradiction with the exercise of reason and reasoning. Imagination provides guidelines for action because it bridges the gap between the possible and the real" (Bensaude-Vincent 2013, p. 25). Notwithstanding the legitimacy of such critiques towards normative synthetic biology, Clark, Thacker, and Bensaude-Vincent do not consider conservation applications, which raises the question of whether their critiques need to be reconsidered in the context of this proposed domain.

Nowadays, for those who do not want the dream to ever be attempted in reality, or for those who see the dream as being a fantasy that could never manifest in the world of Thacker's "concrete results", there is increasingly widespread acknowledgment even amongst the caveat-burdened corridors of academia that the tenure of our species is nearly at its end. In any and all eventualities. Critical theorist 
McKenzie Wark puts it more frankly: "this civilisation is over, and everyone knows it" (Wark 2015). Though the prospects for extinction extent to whether this biosphere is over, and who will admit it?

Of course, if it were already so, then it would be fruitless to entertain proposals for a Synthetic Age. But, when Wark uses the word "over" he means it in terms of the vague timeframe of civilizational collapse- the time it has taken past civilisations to go from inevitably "over" to actually gone has ranged from a matter of months to decades (Diamond 2004; Tainter 1990). Within this unknown temporal window, and operating out of the uncertainty and uncanniness that the spectre of the Anthropocene produces, there remain various competing worldviews that tell us how we should speak responsibly for endangered species and ecologies, and how to act accordingly. The complex ethics involved in formulating and propagating these worldviews and determining our ensuing actions will be discussed below.

Nowadays, those supporting the use of synthetic biology in conservation do so with an acute awareness of the centrality of different worldviews to such issues. For instance, just as Preston seeks a philosophical lens for examining the prospect of a Synthetic Age, there is also a philosophy underpinning the interventionist ethos advocated in 'Is It Time?', which argues that "the opportunity to resolve biodiversity issues may depend on a sea-change of philosophy in the conservation movement to incorporate the application of adapted genomes into the wild" (Piaggio et al. 2017, p. 98). This sea-change may be read both at face value and as metaphor, where the first reading prefigures the second. After all, if rising seas are lapping at your doorstep, would you not abandon outdated worldviews in favour of 'anything goes', given it is self-evident that everything is going under? This is not about pontificating in the armchair corridors of academia, but about making crucial decisions as to whether and how technoscience may be deployed as a life raft for imperilled species.

Taking Preston's Synthetic Age as one framework for conservation in the Anthropocene, what then lies between his philosophy and that of the 'Is It Time' scientists? Or, to phrase it another way: what lies between the dream and the timeframe now available to turn it into reality? Once the rising seas are already lapping at our doorsteps, it is too little, too late to do anything but run away, given that there is a roughly five-decade lag between greenhouse gas emissions and discernible biophysical change. This is not to suggest that the temporal dimension is a mere half century. Rather, future climatic change, sea level rise, and so on, will continue across centuries into millennia, even if all emissions stop today (Archer 2009). Similarly, multitudes of species have already been labelled with the term 'extinction debt', meaning that their future extinction has been securely determined by events which have already transpired (Kuussaari et al. 2009). Such is "the race" that technoscientific conservation is up against. Such are the ecological and evolutionary trends that conservation needs to be considered against.

Dreaming and philosophy may not come to mind as central to considering human-inflected evolution in the context of human-induced extinction, but their underpinning of the entire ethos of technoscientific conservation cannot be so easily discounted. Even Alistair Elfick and Drew Endy, two synthetic biology advocates and practitioners since the field's circa 2003 inception, readily concede that ushering in a Synthetic Age is presently still just a dream:

Scientists and engineers hold a responsibility to consider the impact of the knowledge and technology that they bring to the world. In our imagining, dreaming, and aspiring to create a set of future possibilities, it is clear that as a community, synthetic biologists need to engage in debate with wider stakeholders about the purposes of their work and whether or not these would best be achieved using synthetic biology. (Elfick and Endy 2014, p. 24)

It is precisely this willingness to enter into debate (including debate with those opposed to the field) that arguably distinguishes synthetic biology from other contemporary forms of technoscience. Those proponents of the field who enter into dialogue often attribute their willingness to engage with debate to an open acknowledgement of the grave ethical and moral concerns about the field, and of the formidable imaginary of scientific hubris, from the Industrial Revolution-era of Frankenstein, to the post-apocalyptic-2019 of Blade Runner. 
The dream is encapsulated on the cover of yet another synthetic biology event of 2017: the conference booklet to 'SB7.0: The Seventh International Meeting of Synthetic Biology', issued to the 900 delegates for their four-day conference at the National University of Singapore in June 2016, with Endy as one of the conveners. The cover is a drawing of a rainforest, populated by DNA, microbes, insects, amphibians, fish, birds, and mammals, in particular a lioness. Yet, while the booklet detailed dozens of presentations, the vast majority had no relation to the Anthropocene, or ecological issues in general. The disjuncture is not remarked upon anywhere in conference program itself: Singapore, which means "Lion City", is no longer a jungle, but rather a concrete jungle. The absence of dialogue within the fields that have given birth to the technologies supporting interventionist conservation is particularly worrying given that conservation is no longer about single-issue or single-place preservation, but rather wholesale interventions into ecosystems and evolution itself.

\section{Jungle City}

In 1854, when Alfred Russel Wallace commenced his nine-year-long immersion in South East Asia, the first place he visited was Singapore. His daily fieldwork in jungles peripheral to the then nascent colonial settlement brought him into contact with tigers-not that he saw one, but that he heard them while working there. Even at that point Wallace foresaw the dire consequences of the jungle being cleared to make way for the colonial settlement that was Singapore, remarking that if such destruction was not halted, or at least surveyed and controlled, then:

future ages will certainly look back upon us as a people so immersed in the pursuit of wealth as to be blind to higher considerations. They will charge us with having culpably allowed the destruction of some of those records of Creation which we had it in our power to preserve. (Wallace 1863, p. 210)

By the time he had travelled the globe and studied widely, Wallace had seen first-hand how such human-induced destruction was being repeated the world over, concluding in 1876 that "we live in a zoologically impoverished world, from which all the hugest, and fiercest, and strangest forms have recently disappeared" (Wallace 1876, p. 150). For Singapore, this had taken on another layer of irony by 1930, when tigers had become extirpated, save for domestically bred individuals imprisoned in the island's zoo. Though vast rifts lie between the human-influenced Holocene megafauna extinction that Wallace presciently recognised in 1876, such as regional extirpations of Malayan tigers in Singapore, and the 2017 of 'Is It Time?', 'New Interventions', and 'Engineering Resilience' calls to embark upon technoscientific conservation. Such technoscience is not akin to replanting the rainforests, with a view to making a habitat for a tiger to return to, but rather with 'Bioengineering the Biosphere', as per Richard Sole, or 'Albedo Enhancement by Stratospheric Sulfur Injections', as per Paul Crutzen.

Nowadays, the only place we can find a Singaporean jungle ecosystem and inhabitants as featured on the SB7.0 booklet cover is in the recreated natures of the island's zoo. Just as dreams of restoring some actual jungle are made manifest inside the biotech laboratories of concrete jungles, the SB7.0 commercial, industrial, and academic sponsors show how the field imagines its normative applications extending from human-benefit to benefitting the more-than-human world.

While SB7.0 was no exception in having such aims, this organisation is notable well beyond its status as the key international lynchpin for the burgeoning field of synthetic biology. The 2017 conference was arguably also the first major public 'outing' of synthetic biology for conservation purposes. Day one entreated the delegates, the vast majority of whom were scientists, engineers or other such technical specialists, to a panel on the field's socio-cultural dimensions entitled 'Art, Critique, Design and Our World'. The familiar litany of humanities and social science critique of synthetic biology ensued, showing that Clark's (1997), Thacker's (2003) and Bensaude-Vincent's (2013) concerns still reverberate and therefore remain relevant to the field today. However, there was a telling absence of critique of synthetic biology from non-scientists and the humanities that even remotely engaged with the then-current state of our ecological crisis. 
For instance, one of the panel presenters, the artist Oron Catts, confronted the delegates with a particularly blunt and scathing critique, describing how the field forms part of what he terms the "Single Engineering Paradigm" (Catts and Zurr 2014, p. 28), alongside Crutzen's climate engineering and Sole's biosphere engineering, all of which will combine to manifest Preston's dystopian Synthetic Age. Elsewhere, Catts and fellow artist Ionat Zurr ran through the same litany of objections to synthetic biology for the first five pages of their text on 'Countering the Engineering Mindset: The Conflict of Art and Synthetic Biology', only acknowledging at the bottom of the sixth page that "it is also a time of ecological crisis and its gloomy future predictions" (Catts and Zurr 2014, p. 33).

The fact is, if the humanities are to engage with conservation on its own terms, then it is not "also a time of ecological crisis" - it is only "a time of ecological crisis". Regardless of the actual validity of humanities critique, this really only serves to perpetuate its seeming irrelevance when the existential threats posed to multitudes of species are relegated to page six of an aggressive riposte. To put it bluntly, the humanities and social science continue to engage with the field of conservation technoscience as if the "time of ecological crisis" was merely a background event to critique.

Conversely, for those asking 'Is It Time For Synthetic Biodiversity Conservation', it is truly only "a time of ecological crisis", as they derive their answers to the question in full recognition of how conservation science is decades behind the velocity of biophysical change. For instance, the 'Engineering Resilience' workshop and 'New Interventions' publications occurred the year after the unprecedented global coral bleaching event of 2016-17, which was followed, for the first time in recorded history, by the first ever back-to-back bleaching event of 2017-18, then, yet another first, of the global bleaching event of 2019-20. Events of such frequency and ferocity were not anticipated to occur until the middle of this century, leaving us to ask whether it is not now irrelevant to ask "Is it Time"? Might the correct question be whether it is, in fact, already too late?

Given that such shattered records for ecological upheaval have become everyday affairs, the notion that the excesses of capitalism and consumerism can be reined in, inequality redressed and the tide of human-caused mass extinction stemmed is clearly completely anachronistic at this stage of the Anthropocene. The humanities are still arguing from the point of view of yesteryear conservation, when the situation may have still been salvageable, rather than engaging with the possibility that next to nothing can be saved, no matter what the potential efficacy of technoscientific conservation. As Christopher Preston argues in Climate Justice and Geoengineering: Ethics and Policy in the Atmospheric Anthropocene:

Many of the best options for dealing with the escalating climate problem are no longer on the table. The options that remain are increasingly far from ideal. What might have been a slow and orderly transition to a low-carbon economy will now have to be a rapid and lurching one. What might have been a timely and balanced research and development path away from fossil fuels and towards clean technologies will now have to be an almost impossibly quick one. Where climate engineering once looked outlandish or even repulsive, it is now becoming increasingly credible to growing numbers of observers. (Preston 2016, p. xi)

Writing in 2016, Preston illustrates the sizeable replies that had amounted in the 10 years following Crutzen's 'Albedo Enhancement' publication in 2006. In this vein, Catts and Zurr's "gloomy future predictions" have already arrived, although, as William Gibson put it, "the future has already arrived, it is just not evenly distributed" (Gibson 2003). The future of technoscientific conservation will not be evenly distributed either, given how the economic and political disparities that fuelled the current crisis will inequitably impact on the attempted technofixes.

Day two of SB7.0 brought the focus back to those who seek to act upon these "options that remain [that] are increasingly far from ideal" for responding to human-caused extinction. In the panel session on 'Biodiversity \& Conservation', eight scientists and conservation practitioners each delivered 12-min proposals for using synthetic biology in conservation. Their proposals pertained to endangered species, ranging from enhancing the resistance of the American chestnut tree to a fungal 
blight brought over a century ago in transplanted trees from Japan, enhancing the thermal tolerance of coral, synthesising the blood of the Horseshoe crab so that it is no longer harvested for its blood to be used for human vaccination manufacture, making malarial mosquitoes all male so that they cannot breed, to reduce malaria, and likewise making invasive rodents on secluded islands all male so that they cannot breed, to reduce island extinctions caused by the rodents. One of the presenters, Sonja Luz, Director of Conservation and Research at Wildlife Reserves Singapore, brought a local focus, talking about the pocket of recreated jungle in the zoo where the island's sole tigers now live in captivity, and her receptivity to what synthetic biology could mean for zoo-based conservation. In the question-and-answer session following, the presenters were inundated with enthusiastic responses from delegates: it should be noted that, for most of the delegates, these new conservation applications represented an extreme departure from the normative applications which dominate the field. Through such outreach conferences, the dream gets extended beyond the fringe and into the mainstream, gaining currency via newfound interest from the commercial, industrial and academic stakeholders in attendance.

If 2017 was the year when synthetic biology and conservation biology left the margins and entered the mainstream of technoscientific conservation, 2018 was the year when these strange bedfellows began to be taken seriously, beyond the realm of TED talks and industry conferences. In April 2018, the Joint Task Force and Technical Working Group of the International Union for the Conservation of Nature (hereafter IUCN) convened at Jesus College, Cambridge, for the first meeting of the Synthetic Biology and Biodiversity Conservation project. The peak international body for the "Conservation of Nature" is researching the efficacy of synthetic biology amidst the unfolding Sixth Extinction Event. The answer to the question 'Is It Time?' is quite simply that it has now come to this.

\section{Intervention Is Better than Cure}

If it is time for novel worldviews, as per the Anthropocene, and, arguably, for novel conservation practices, then it is also time to reconsider the role of language in framing a stance toward both. The Kafkaesque absurdity of the IUCN Task Force nomenclature throws the inadequacies of concepts of 'natural', 'artificial' and 'conservation' into sharp relief: 'natural', for example, raises a self-contradiction inherent to the interventionist ethos. Humans are accustomed to perceiving themselves outside of, or opposed to, nature. But, given that the Anthropos is part of nature, including, therefore, all the products of our labours, how can our modes of inhabiting the earth, no matter how catastrophically irresponsible and disastrous, be an act of 'intervening' in that-which-we-are-always-inextricably-part-of? Surely we have only ever been working with and within nature, however unsuccessfully, and not merely 'intervening' in 'nature'? Just as we have been worked on by 'nature' too, and just as we are composed of 'nature.' For we are 'nature', along with the entirety of the living and non-living world, as well as the cosmos to which this particular planet is hitched.

When Raymond Williams observed that nature is "perhaps the most complex word in the [English] language" he was not engaging in mere semantics, but rather pointing out the prevalence for different interpretations of 'nature' as a word, and how they manifest vastly different worldviews. And, further, since it is

a word which carries, over a very long period, many of the major variations of human thought—often, in any particular use, only implicitly yet with powerful effect on the character of the argument-it is necessary to be especially aware of its difficulty. (Williams 2014, p. 169)

Therein, we see that when the 'Is It Time?' co-authors nod to how "the opportunity to resolve biodiversity issues may depend on a sea-change of philosophy in the conservation movement" (Piaggio et al. 2017, p. 98), this sea-change pivots on highly contested worldviews about what is nature, and thus what is natural, more so than any other concept.

This pivot has further repercussions for an interventionist ethos, as Williams presciently observed in 1980, stating that "we have mixed our labour with the earth, our forces with its forces too deeply to 
be able to draw back and separate either out" (Williams 1980, p. 83). This means distinctions between what is natural versus what is cultural, social, synthetic or artificial-i.e., human-are increasingly indiscernible and arguably the product of false distinctions arising from Enlightenment rationality, so-called. While the word 'conservation' does not command the same level of "difficulty" as 'nature', it too fosters worldviews that are incommensurate with the more-than-human world itself. Put plainly, the meanings of the word were decidedly different for the half a millennium before it came to refer to conservation of 'nature' with the emergence of modern environmentalism in the 1950s. Then again, every word-at-stake warrants such scrutiny, as Eileen Crist points out with regard to the notion of the Anthropocene, in her treatise 'On the Poverty of Our Nomenclature' (Crist 2013).

With regard to conservation through synthetic biology, this means that the term 'human-directed evolution' cannot represent the endeavour, nor can analogous conjoined terms such as '-designed', '-engineered', or '-inflected'. The "poverty of our nomenclature" concerning human effects on evolution is palpably brought to light in the artist and biologist Angelo Vermeulen's (2006) interactive installation Blue Shift. Here, Vermeulen demonstrates a human-influenced microevolution of water fleas housed in aquaria connected to custom electronics. In the absence of any humans, yellow lights illuminate the aquaria from above, attracting the fleas to the upper water register. In the presence of nearby humans, sensor beams within the installation are intercepted, triggering blue lights above the aquaria instead. For water fleas, blue light indicates open ocean, where they are subject to higher predation than shallow water, indicated by yellow light.

However, Blue Shift deliberately tricks the water fleas: those that instinctively swim away from the blue light pass through a false bottom, housing fish which eat them. Thus, only those water fleas who (counter-intuitively) do not swim away from the blue light go on to survive and reproduce, manifesting a form of microevolution by conferring genetic traits for not-swimming-away-from-blue-light onto their descendants. Setting aside the ethical issues raised by using non-human creatures for the purposes of art, as well as other variables, such as how many generations are bred within Blue Shift, and whether the fleas are released into an open ecosystem or not after a presentation of the installation concludes, the question of whether this is human '-directed', '-designed', '-engineered', or '-inflected' evolution remains an open question. The agency appears to possess something from each category, and yet no category can remotely capture the complexity of the agency at play here, even in this seemingly simple example.

A corresponding "poverty of our nomenclature" pertains to evolution vis-à-vis synthetic biology for conservation, yet with inscrutably more complex agency and causality. This raises intractable challenges for the ethics of such conservation given that these ethics arise according to the efficacy of the conservation. If the endeavour is, after all, a dream with no efficacious transferral into reality, then the corresponding ethical debate remains academic, in the sense of privileged detachment from the ecological crisis unfolding. This is ultimately due to the fact that proposed conservation is conditional on five chronological stages of experimentation: in silico, in vitro, in vivo, ex situ, in situ. And, here, the stakes are all the more ultimate; genetic and microbial interventions can only be remotely assayed when considered in their respective evolutionary contexts. If a genetic intervention is not inherited by a sufficient number of the modified organism's descendants, then it becomes as ephemeral as the life of that population of individuals.

Furthermore, there is no singular discrete 'intervention' taking place. The Anthropocene thesis holds that the entirety of the Earth System has been rendered into a planetary-scale Blue Shift, though, in the scaling up, any discrete chains of causality have become subsumed within the incalculable forcings of human progeny, coupled with those of inhuman, nonhuman, and more-than-human progeny. As Wallace Broecker declared in 1987, with regard to human-caused climate change:

The inhabitants of Earth are quietly conducting a gigantic experiment. So vast and sweeping will be the consequences that, were it brought before any reasonable council for approval, it would be firmly rejected. Yet it goes on with little interference from any jurisdiction or nation 
... We play Russian roulette with climate, hoping that the future will hold no unpleasant surprises. No one knows what lies in the active chamber of the gun. (Broecker 1987, p. 124)

Ethics applied to the 'intervening' in this "gigantic experiment" must grapple with domains and dominions that not only eviscerate categorical distinctions between the inhuman, nonhuman, and more-than-human, but also with the pitfalls that result from privileging "matters of concern" over "matters of fact." (Latour 2004).

\section{Time's up}

Just as humanities scholarship all too often falls short in its attempts to engage with the science of biology (whether evolutionary, conservation, or synthetic), so too are scientists' limitations revealed by their attempts to critically scrutinise the "matters of concern" raised by the humanities about their own work. This was exemplified in a 2000 National Academy of Sciences conference on The Future of Evolution, when only one of the papers presented mentioned ethics at all: Paul Ehrlich's 'Intervening in Evolution: Ethics and Actions.' Ehrlich opened with a framing that, while not uncommon in scientific literature at the time, is ubiquitous two decades later, and not just in the sciences but across the humanities and social sciences: "There is no question that Homo sapiens, in addition to causing the sixth major spasm of biotic extinction, is also altering the course of evolution for millions of years in the future" (Ehrlich 2002, p. 5476). Following this opening, Ehrlich devotes the four pages of his paper to "what ethical obligations might this impose on scientists to respond in various ways? And ... what might scientists do to be more effective in informing society of its options in this area?" (Ehrlich 2002, p. 5477). Yet, like Wilson in The Future of Life, Ehrlich laments how "the speed at which society is changing the evolutionary prospect seems fated to remain much more rapid than the rate at which society is developing ethics to deal with the challenges that change may present" (Ehrlich 2002, p. 5478).

The divergent paths have only become all the more pronounced in the two decades since, including between synthetic biology proponents and opponents. In his impassioned Defiant Earth: The Fate of Humans in the Anthropocene philosopher Clive Hamilton laments how the science that has evinced the Anthropocene has also unleashed "a paradigm shift in the earth sciences" which in turn "is prompting an ontological shift in self-understanding and the human-Earth relation, although it is tragically true that the science is decades ahead of the zeitgeist" (Hamilton 2017, p. 52). For instance, on the subject of 'Intervening in Evolution: Ethics and Actions', Ehrlich simply declared that scientists could "be more effective in informing society of its options in this area" (Ehrlich 2002, p. 5479).

Such a notion of the relationship between science and society is premised on the information-deficit model, which holds that lay citizens would make informed (and, by implication, rational) decisions pending sufficient accessible information about a scientific subject. For instance, this model presumes that, if the lay citizenry understood climate science better, they would then make less selfish, short-term, and self-destructive decisions about what climate policy to support. However, such simplistic worldviews have shown themselves to be grossly inapplicable to the notional "options" at hand. Regarding The Fate of Humans in the Anthropocene, Hamilton boils these "options" down to an overly simplistic framework, albeit one without any equivalent and no sense of the real impending peril:

Humankind is now confronted with a momentous decision: to attempt to exert more control so as to subdue the Earth with greater technological power-the express purpose of some forms of geoengineering - or to draw back and practice meekness, with all of the social consequences that would follow. (Hamilton 2017, p. 17)

While he is not referring to synthetic biology specifically, the principles apply nonetheless, as per Catts and Zurr's earlier summation of the Single Engineering Paradigm. In any case, it is patently obvious that today's "zeitgeist" is anything but informed and rational, least of all when it comes to using technoscience for conservation. This is because stances toward conservation are deeply shaped by emotions, rather than the ideas of a sufficiently well-informed and verifiably rational actor. Ehrlich acknowledges this when he states that his preferred form of conservation practice, which would be to 
bolster networks of national parks as 'wildlife corridors' across continents, is "where I would come down emotionally if I could ignore the practical and ethical complexities", whereas he declares the opposing extreme to be the "technological optimists who assume that genetic engineers will soon be able to produce any needed biodiversity" (Ehrlich 2002, p. 5480).

This blurring between "matters of fact" and "matters of concern" has telling expressions in the scientific framing of synthetic biology for conservation. Putting Ehrlich's concerns into contemporary practice, biologist Kevin Esvelt researches gene drives for purposes such as making all structurally integrated populations of mosquitos or invasive rodents male, in order to eradicate them from a region or island, respectively. Sculpting Evolution, the name Esvelt gave to the group he founded at MIT Media Lab, speaks volumes about the categorical errors of our language, let alone our actions, in terms of recognising what is at stake. Whether a single scientist operating on the micro-scale of synthetic biology or a team operating on the macro-scale of climate engineering, there is no human agency for Sculpting Evolution, as if evolution itself were some innate matter that yields to our every whim.

Esvelt conducts public talks, op-eds, blogs and interviews where he candidly acknowledges the profound ethical dilemmas that his work raises. And yet, like relegating the discussion of ethics in relation to The Future of Evolution to a mere four pages in the eponymous edited volume, none of Esvelt's academic publications or public engagement evidences any study of, or collaboration with, actual ethicists (Esvelt et al. 2014; Esvelt and Gemmell 2017). This is not to suggest that Ehrlich, Esvelt, or any other scientist should perform the work of an ethicist, though the problem persists that scientists and ethicists are largely talking to one another exclusively in relation to "matters of concern" about multitudes of imperilled species. To scale up this Blue Shift-sized disjuncture to the planet: even if Esvelt or other such scientists collaborated with ethicists, no ethical framework genuinely commensurate with Hamilton's "momentous decision" of whether or not to deploy technoscientific conservation could ever actually be formed. Hamilton thus concludes his book on The Fate of Humans in the Anthropocene with a confession from a Professor of Public Ethics: "we have to confront the most difficult truth-in the Anthropocene we have no ethical resources to draw on. The cupboard is bare" (Hamilton 2017, p. 110).

Such is the challenge now facing not only scientists and philosophers of technoscientific conservation but the assembling policy makers, bureaucrats, legal scholars and others who mediate between dreams born of a cultural imaginary and their translation into reality. Of course, while this article focuses on societies embedded in developed-world democratic institutions and dynamics, we must also recognise the existence of societies where no consultation of either ethics or the population at large will be deemed necessary before in situ experimentation with these technologies commences, further undermining the idea that any worldview can remotely fathom the complexity, uncertainty and volatility of the state of play. Here, however, we focus on the disjuncture occurring in western democracies, and as Clark reminds, today's disjuncture harks back to Ulrich Beck's 1985 landmark Risk Society hypothesis about industrial modernity in the Global North (Beck[1985] 1992). Reflecting in 1998 on Beck's hypothesis, Clark once again showed a telling prescience for the situation at hand:

As we seek to intervene in realms that we now understand to be composed of great numbers of parts undergoing a kaleidoscopic array of simultaneous interactions, a new set of demands is placed on the technological apparatus. Whatever the amount of intelligence we can program into our sub-micro or macro machine systems, the encounter with conditions of non-linearity is likely to call for responses which exceed our capacity to make sense of the situation. (Clark 1998, p. 362)

In words that radically undermine claims toward definitive guidelines and principles, as per august bodies such as the IUCN Synthetic Biology and Biodiversity Conservation Task Force, Clark lamented back then how this disjuncture

presents an enormous challenge to theory, which in relation to the frenetic feedback mechanisms of the new global networks appears as a lag-ridden and slow-replicating 
edifice ... call[s] for public accountability of the scientific and economic apparatus seems to offer only the drag coefficient of a lost linear modernity-a world of processes ponderous enough to still allow for the fantasy of collective steering. (Clark 1998, p. 366)

Thus, given the ends for which genetic and microbial interventions are intended, it is imperative to engage with these domains on something approximating their own terms. For, in these inhuman, nonhuman, and more-than-human domains lies the dream of human-inflected evolution as a counterpoint to human-induced extinction. In turn, the following presents an inconclusive conclusion, acknowledging that the questions asked here must largely remain both open-ended, and without definitive answers.

\section{Closed Minded and Open-Ended}

In the question-and-answer session following the 'Biodiversity \& Conservation' panel at SB7.0, one of the presenters, Kent Redford, told the audience how the session's origins went back to 2013, when the world's first such meeting between synthetic and conservation biologists took place (Redford 2013). Held at Cambridge University, 'How will Synthetic Biology and Conservation Shape the Future of Nature?' brought these strange bedfellows together over three days of presentations and workshops. Redford, who convened this 2013 symposium, has since been instrumental in organising, facilitating, and convening a series of events that directly followed on from the original symposium, as well as in writing and publishing the working papers, reports, guidelines, and academic papers that emerged from these events. These events included 'The New Genomic Solutions for Conservation Problems Workshop' with the U.S. NGO Revive E Restore in 2015; 'Biodiversity Conservation in the Context of Synthetic Biology' workshop with the IUCN and the Rockefeller Foundation, also in 2015; 'Advancing Genetic Rescue' at the World Conservation Congress in 2016; convening the 'Biodiversity \& Conservation' panel in 2017; forming the IUCN Task Force and a Technical Subgroup in 2018; and overseeing its policy outcomes for the World Conservation Congress in 2020.

Originally a conservation biologist, Redford is arguably emblematic of the shift from normative to experimental technoscientific conservation and also played a key role in recognising the relevance of the cultural imaginary underpinning the dream of implementing this shift. In his SB7.0 presentation, Redford not only included Raymond Williams' aforementioned landmark interrogation of the concept of 'nature', and its relevance for technoscientific conservation, but also emphasised just how tenuous, uncertain, and hubristic the dream is. He did so by way of a lengthy quote from Sheila Jasanoff, Professor of Science and Technology Studies at the Harvard Kennedy School, from her "call [for] the 'technologies of humility'", which she defines as:

Institutionalized habits of thought, that try to come to grips with the ragged fringes of human understanding - the unknown, the uncertain, the ambiguous, and the uncontrollable. Acknowledging the limits of prediction and control, technologies of humility confront 'head-on' the normative implications of our lack of perfect foresight. They call for different expert capabilities and different forms of engagement between experts, decision-makers, and the public than were considered needful in the governance structures of high modernity. They require not only the formal mechanisms of participation but also an intellectual environment in which citizens are encouraged to bring their knowledge and skills to bear on the resolution of common problems. (Jasanoff 2005, p. 227)

Which is to say that, in the context of technoscientific conservation, even those extensively engaged in the field, and in possession of the relevant scientific and/or technical expertise, maintain that the dream requires humility, not hubris. Indeed, Bensaude-Vincent offers a cautionary note when she argues that "the novel forms of life will not escape the contingencies of evolution. Since all synthetic organisms will have to take place in the world, it is unrealistic to imagine that they will have a predictable behaviour. If they are capable of evolution they are not under human control" (Bensaude-Vincent 2013, p. 30). As always-there is a more extant history behind such dreams, with 
Clark remarking back in 1998 that "there is a price to be paid for this novel capacity to deal with multivariate and simultaneous interactions, which is a certain loss of control-a devolution of authority from a central programmer to the synthetic system itself" (Clark 1998, p. 362).

One of the other presenters at SB7.0, the British designer and academic Alexandra Daisy Ginsberg, offered a complementary tone to Redford and Jasanoff, albeit from a design rather than a scientific point of view. Having attended the 'How will Synthetic Biology and Conservation Shape the Future of Nature?' symposium in 2013, Ginsberg viewed the nascent field through the lens of her critical design practice. In turn, she created 'Designing for the Sixth Extinction', a series of fictional new-to-nature creatures, created by companies to perform bioremediation and biodiversity offsetting. Like the SB7.0 booklet cover, her designs consisted of computer-generated creatures realistically placed into photographs of actual forests, accompanied by a patent statement for each that outlined the ownership of its intellectual property, as well as its commercial value, protected through measures such as kill-switches designed to terminate the creature after a programmed duration, so that the companies' services will always be required to manufacture more of them.

Ginsberg's work captures both the ongoing validity of the humanities' critique of the field, including the need for humility, as well as a measured acknowledgement that it does indeed appear to be "Time for Synthetic Biodiversity Conservation", albeit a version of that conservation that radically redefines core concepts, including the notion of humility itself:

Our greatest challenge may be to acknowledge that the design rules for biology are unlike those for any other material. Human intention may not be enough to overcome evolution. Synthetic biology's designs on nature require us to adapt our understanding of design, the natural world, and life itself. (Ginsberg 2014, p. 56)

Regrettably, Ginsberg's practice is a typically isolated instance of cultural engagement with synthetic biology, meaning that the all-important cultural imaginary can too easily be conflated with the scant examples of such engagement. This imaginary is distributed across and between diverse stakeholders, though it is commonly reduced to whatever cultural artefacts exist, as a synecdoche for the intangible and inexpressible properties of a dream. Just as Jurassic Park was used as a short-hand description of the cultural imaginary of de-extinction in its time, so too is Ginsberg's Design for the Sixth Extinction a short-hand for our time, although any such proxies are never the sole progeny of the cultural imaginary: this imaginary is also fashioned in the laboratory, the boardroom, the policy document, and other such 'non-cultural' spheres.

This issue was brought to the fore by Oliver Morton, another presenter at SB7.0. His paper was a highly unusual presentation in the context of a synthetic biology conference, replete with examples drawn from myths, paintings, poetry and other cultural artefacts. Morton began his presentation by talking about a key juncture in developing his book The Planet Remade: How Geoengineering Could Change the World. He recounted how his publisher advised him to include synthetic biology as well as climate engineering, given the former presents micro-scale, and the latter macro-scale, as proposals to mitigate the Anthropocene. Morton then explained how he resisted the advice, only to regret it later, having subsequently come to appreciate the manifold ways in which the two fields are two sides of the same coin. Essentially, Morton's presentation encapsulated the rationale for The Planet Remade, which he described as an attempt to counter what happens when

the possibilities of utopian imagination ... are undercut, even betrayed, if the group doing the imagining is too small. That is currently the case, I think, for geoengineering. Listen to the discussion of the topic going on today and you will hear natural scientists who are cautiously curious about the ideas but have no real interest in trying to make them practical; you will hear social scientists and philosophers interested in providing critiques of the modes of thinking that shape the discourse; you will hear environmentalists who see in it, or project on to it, everything they dislike about centralized action, about capitalism, about mechanistic world views; you will hear the fantasies of the rich and powerful and the fears 
of the frightened and doctrinaire. It is too small a set of voices. The way a society imagines its future matters. And who gets to do the imagining matters. (Morton 2017, p. 29)

During the conclusion to his presentation, the projected image above the stage changed from depicting the above-mentioned cultural artefacts, to return to the conference logo, a modified version of the image which adorned the booklet. The portrait presentation for the booklet had been turned into a circular motif, symbolising the earth, with Singapore's skyscrapers emerging above the surface, an outer layer composed of microbes, and an inner layer composed of the same plants and animals from the conference booklet cover, and finally an innermost layer comprising the conference title SB 7.0 with eight human hands radiating out around the circle, in different skin tones to represent the diverse ethnicities and races of the differentiated Anthropos subsumed into the singular Anthropocene. This imagery presents the dream as if it were about future action, as per How Geoengineering Could Change the World, whereas those who have already awoken realise we are no longer fantasising but are already living within the dream itself.

SB7.0 was staged at the University Cultural Centre within the National University of Singapore, a kilometre from where the shoreline was when Wallace stayed there in 1854 . Nowadays, one would need to travel a further 300 metres to reach the shoreline, to cross the land that has been reclaimed from the ocean through dredging, sand relocation and engineering. Which is to say that it is not so much about asking "Is it Time for Synthetic Biodiversity Conservation", but rather time to acknowledge that we already inhabit a planet rife with the artifice and artificiality of design and engineering. At the same time, we must acknowledge that, however audacious the current proposals to extend this agency may be, they invoke increasing incursions into the inhuman, non-human and more-than-human world. Incursions, that it turns out, reveal technoscientific conservation in the Anthropocene to paradoxically be both vital and futile, as well as timely and too late.

Funding: This research was funded by the Australian Research Council Centre of Excellence in Synthetic Biology (CE200100029). The views expressed herein are those of the author and are not necessarily those of the Australian Government or the Australian Research Council.

Acknowledgments: My thanks to Rubymaya Jaeck-Woodgate for feedback and editing successive drafts.

Conflicts of Interest: The author declares no conflict of interest.

\section{References}

Anthony, Ken, Line Bay, Robert Costanza, Jennifer Firn, John Gunn, Peter Harrison, Andrew Heyward, Petra Lundgren, David Mead, Tom Moore, and et al. 2017. New Interventions Are Needed to Save Coral Reefs. Nature Ecology \& Evolution 1: 1420-22.

Archer, David. 2009. The Long Thaw: How Humans Are Changing the Next 100,000 Years of Earth's Climate. Princeton: Princeton University Press.

Beck, Ulrich. 1992. Risk Society: Towards a New Modernity. London: SAGE. First published 1985.

Bensaude-Vincent, Bernadette. 2013. Between the Possible and the Actual: Philosophical Perspectives on the Design of Synthetic Organisms. Futures 48: 23-31. [CrossRef]

Broecker, Wallace. 1987. Unpleasant surprises in the greenhouse? Nature 328: 123-26. [CrossRef]

Catts, Oron, and Ionat Zurr. 2014. Countering the Engineering Mindset: The Conflict of Art and Synthetic Biology. In Synthetic Aesthetics: Investigating Synthetic Biology's Designs on Nature. Edited by Ginsberg Alexandra Daisy, Jane Calvert, Pablo Schyfter, Alistair Elfick and Drew Endy. Cambridge: MIT Press, pp. 28-38.

Clark, Nigel. 1997. Panic Ecology: Nature in the Age of Superconductivity. Theory, Culture \& Society 14: 77-96.

Clark, Nigel. 1998. Nanoplanet: Molecular Engineering in the Time of Ecological Crisis. Time \& Society 7: 353-68.

Coleman, Melinda, and Hugh Goold. 2019. Harnessing Synthetic Biology for Kelp Forest Conservation. Journal of Phycology 55: 745-51. [CrossRef] [PubMed]

Crist, Eileen. 2013. On the Poverty of Our Nomenclature. Environmental Humanities 3: 129-47. [CrossRef]

Crutzen, Paul. 2006. Albedo Enhancement by Stratospheric Sulfur Injections: A Contribution to Resolve a Policy Dilemma? Climatic Change 77: 211-20. [CrossRef] 
Crutzen, Paul, and Christian Schwägerl. 2011. Living in the Anthropocene: Toward a New Global Ethos. Yale E360. Available online: https://e360.yale.edu/features/living_in_the_anthropocene_toward_a_new_global_ethos (accessed on 9 July 2020).

Diamond, Jared. 2004. Collapse: How Societies Choose to Fail or Succeed. New York: Viking.

Ehrlich, Paul. 2002. Intervening in Evolution: Ethics and Actions. In (NAS Colloquium) the Future of Evolution. Edited by National Research Council. Washington, DC: National Academies Press.

Elfick, Alistair, and Drew Endy. 2014. Synthetic Biology: What It Is and Why It Matters. In Synthetic Aesthetics: Investigating Synthetic Biology's Designs on Nature. Edited by Ginsberg Alexandra Daisy, Jane Calvert, Pablo Schyfter, Alistair Elfick and Drew Endy. Cambridge: MIT Press, pp. 15-26.

Esvelt, Kevin, and Neil J. Gemmell. 2017. Conservation Demands Safe Gene Drive. PLoS Biology 15: e2003850. [CrossRef] [PubMed]

Esvelt, Kevin, Andrea L. Smidler, Flaminia Catteruccia, and George M. Church. 2014. Concerning RNA-guided Gene Drives for the Alteration of Wild Populations. eLife 3: 57. [CrossRef] [PubMed]

Gibson, William. 2003. Books of the Year 2003. The Economist, December 4.

Ginsberg, Alexandra Daisy. 2014. Design as the Machines Come to Life. In Synthetic Aesthetics: Investigating Synthetic Biology's Designs on Nature. Edited by Ginsberg Alexandra Daisy, Jane Calvert, Pablo Schyfter, Alistair Elfick and Drew Endy. Cambridge: MIT Press, pp. 39-72.

Hamilton, Clive. 2017. Defiant Earth: The Fate of Humans in the Anthropocene. New York: Polity.

Jasanoff, Sheila. 2005. Technologies of Humility: Citizen Participation in Governing Science. In Wozu Experten? Edited by Alexander Bogner and Helge Torgersen. Wiesbaden: VS Verlag für Sozialwissenschaften, pp. 370-89.

Kuussaari, Mikko, Riccardo Bommarco, Risto Heikkinen, Aveliina Helm, Jochen Krauss, Regina Lindborg, Erik Öckinger, Meelis Pärtel, Joan Pino, Ferran Rodà, and et al. 2009. Extinction Debt: A Challenge for Biodiversity Conservation. Trends in Ecology \& Evolution 24: 564-71.

Latour, Bruno. 2004. Why Has Critique Run out of Steam? From Matters of Fact to Matters of Concern. Critical Inquiry 30: 24. [CrossRef]

Morton, Oliver. 2017. The Planet Remade: How Geoengineering Could Change the World. Princeton: Princeton University Press.

Piaggio, Antoinette, Gernot Segelbacher, Philip Seddon, Luke Alphey, Elizabeth Bennett, Robert Carlson, Robert M. Friedman, Dona Kanavy, Ryan Phelan, Kent Redford, and et al. 2017. Is It Time for Synthetic Biodiversity Conservation? Trends in Ecology \& Evolution 32: 97-107.

Preston, Christopher, ed. 2016. Climate Justice and Geoengineering: Ethics and Policy in the Atmospheric Anthropocene. New York: Rowman \& Littlefield International.

Preston, Christopher. 2018. The Synthetic Age: Outdesigning Evolution, Resurrecting Species, and Reengineering Our World. Cambridge: MIT Press.

Redford, Kent, ed. 2013. How Will Synthetic Biology and Conservation Shape the Future of Nature? A Framing Paper. New York: Wildlife Conservation Society, pp. 1-30.

Redford, Kent, William Adams, and Georgina Mace. 2013. Synthetic Biology and Conservation of Nature: Wicked Problems and Wicked Solutions. PLoS Biology 11: e1001530. [CrossRef] [PubMed]

Redford, Kent, Thomas M. Brooks, Nicholas Macfarlane, and Jonathan Adams, eds. 2019. Genetic Frontiers for Conservation: An Assessment of Synthetic Biology and Biodiversity Conservation: Technical Assessment. Gland: IUCN, International Union for Conservation of Nature.

Solé, Ricard. 2015. Bioengineering the Biosphere? Ecological Complexity 22: 40-49. [CrossRef]

Soulé, Michael. 1985. What Is Conservation Biology? BioScience 35: 11.

Tainter, Joseph. 1990. The Collapse of Complex Societies. Cambridge: Cambridge University Press.

Thacker, Eugene. 2003. The Science Fictioning of Biotechnology. 032c 4: 106.

Vermeulen, Angelo. 2006. Blue Shift, Cultuurcentrum, Hasselt, Belgium. Available online: http://www. angelovermeulen.net/?portfolio=blue-shift-log-1 (accessed on 10 July 2020).

Wallace, Alfred Russel. 1863. On the Physical Geography of the Malay Archipelago. The Journal of the Royal Geographical Society of London 33: 217-34. [CrossRef]

Wallace, Alfred Russel. 1876. The Geographical Distribution of Animals, with a Study of the Relations of Living and Extinct Faunas as Elucidating Past Changes of the Earth's Surface. New York: Harper. 
Wark, McKenzie. 2015. This Civilization Is Over. And Everybody Knows It. Versobooks.Com. Available online: https://www.versobooks.com/blogs/1950-this-civilization-is-over-and-everybody-knows-it (accessed on 10 July 2020).

Williams, Raymond. 1980. Problems in Materialism and Culture: Selected Essays. London: Verso, pp. 67-85.

Williams, Raymond. 2014. Keywords: A Vocabulary of Culture and Society. Oxford: Oxford University Press. Wilson, Edward. 2003. The Future of Life. New York: Vintage.

Wodak, Josh. 2019. When Water Meets Oil: Rupturing Rhetoric and Reality in Energy Policy and Climate Science. In The Rhetoric of Oil in the Twenty-first Century: Government, Corporate, and Activist Discourses. Edited by Heather Graves and David Beard. Philadelphia: Routledge, pp. 72-89.

Publisher's Note: MDPI stays neutral with regard to jurisdictional claims in published maps and institutional affiliations.

(C) 2020 by the author. Licensee MDPI, Basel, Switzerland. This article is an open access article distributed under the terms and conditions of the Creative Commons Attribution (CC BY) license (http://creativecommons.org/licenses/by/4.0/). 